\title{
RETROSPECTIVE STUDY OF PAROTID NEOPLASMS IN A TERTIARY HOSPITAL
}

\author{
V. Bhanumathi' ${ }^{1}$ S. Venkataramana Rao ${ }^{2}$
}

${ }^{1}$ Associate Professor, Department of Surgery, Mediciti Institute of Medical Sciences, Ghanpur, Telangana.

2Professor, Department of ENT, Mediciti Institute of Medical Sciences, Ghanpur, Telangana.

\section{ABSTRACT}

\section{BACKGROUND}

Neoplasms of the salivary gland are rare tumours with an annual incidence of 1:100000. It comprises 3\% of Head and Neck Neoplasms.[1] In salivary gland tumours, the mean age is 45 years with peak incidence in $6^{\text {th }}$ and $7^{\text {th }}$ decade of life.[2,3] The most frequent site for salivary neoplasm is parotid gland.[4-6] Around $80 \%$ of parotid tumours are benign, the commonest being pleomorphic adenoma followed by Warthin's tumour. Most common salivary malignancy is mucoepidermoid carcinoma involving the parotid gland.[5,7] Adenoid cystic carcinoma is the second most common malignancy.

\section{MATERIALS AND METHODS}

In this series, various aspects of the parotid tumours admitted in MediCiti Institute of Medical Sciences from January 2012 January 2017 in the Department of General Surgery and ENT were analysed. A detailed study of 42 cases of parotid tumour admitted during this period is carried out. Our study comprises of benign and malignant tumours of the parotid gland and the results are compared with the data available in the literature. Study design is retrospective descriptive study.

\section{RESULTS}

Majority of salivary gland tumours arise from parotid gland. The mean age was 51.05 years. The present study exhibits an incidence of $64.3 \%$ benign tumours and $35.7 \%$ malignant tumours with pleomorphic adenoma accounting for $85.18 \%$ of benign tumours and about $54.76 \%$ of all parotid neoplasms.

\section{CONCLUSION}

Neoplasms of parotid gland are most commonly encountered salivary neoplasms. Most of them are benign. About $80 \%$ of primary salivary gland epithelial tumours are seen in parotid gland, mostly in superficial lobe. The peak age incidence was in the $50-60$ years' age group. Benign tumours, particularly pleomorphic adenoma is commonest presentation and the commonest malignant tumour is mucoepidermoid carcinoma.

\section{KEYWORDS}

Parotid Gland, Neoplasm, Pleomorphic Adenoma, Mucoepidermoid Carcinoma, Adenoid Cystic Carcinoma.

HOW TO CITE THIS ARTICLE: Bhanumathi V, Rao SV. Retrospective study of parotid neoplasms in a tertiary hospital. J. Evolution Med. Dent. Sci. 2017;6(72):5103-5106, DOI: 10.14260/jemds/2017/1109

\section{BACKGROUND}

Salivary gland neoplasms constitute $3 \%$ of Head and Neck neoplasms with mean age around 45 years. Benign salivary gland tumours are more frequently encountered in females whereas malignant tumours are more frequently encountered in males. The most frequent site of salivary neoplasm is parotid gland. Most of the parotid tumours are benign $(80 \%)$ and the most common benign tumour is pleomorphic adenoma followed by Warthin's tumour. The most common malignant tumour is mucoepidermoid carcinoma followed by adenoid cystic carcinoma. Salivary gland neoplasms have diverse histopathology and variable biological course. Parotid gland has an intimate anatomical relationship with the facial nerve, presence of intraparotid lymph nodes and a deep lobe. The consequence of sacrificing the facial nerve may at times constitute a deterrent to the performance of adequate surgery for tumour arising from the

Financial or Other, Competing Interest: None.

Submission 25-07-2017, Peer Review 25-08-2017,

Acceptance 31-08-2017, Published 07-09-2017.

Corresponding Author:

Dr. S. Venkataramana Rao,

8-53/2, North Kamalanagar,

ECIL Post,

Hyderabad-500062.

E-mail: syamjivenkat19@gmail.com

DOI: $10.14260 /$ jemds $/ 2017 / 1109$
Parotid gland. Moreover, parotid gland cancers have a variable biological course and do not follow the general familial survival pattern of squamous cell carcinomas of the head and neck. The Parotid gland benign tumours are less benign and the malignant tumours are less malignant as compared to benign and malignant tumours of the head and neck tumours. Because of this variation, the success of treatment and ultimate prognosis can be expressed, not in 5 years or 10 years but rather in 20 years. Perhaps no tissue in the body is capable of producing such a diverse histopathological expression than the parotid gland tissue due to the presence of myoepithelial cells in the parotid. Because of this, the tumour surgery is coupled with other forms of therapy such as radiotherapy and chemotherapy for better results.

\section{Objective}

To study the incidence of various parotid neoplasms attending a tertiary hospital, i.e. MediCiti Institute of Medical Sciences, Medchal, Telangana.

\section{MATERIALS AND METHODS}

In this study, various aspects of the parotid tumours are analysed in the cases admitted in MediCiti Institute of Medical Sciences from January 2012 - January 2017 in the Department of Surgery and ENT. All these cases are compared with the data available in the literature and a 
detailed study of 42 cases of parotid tumour is carried out. Study design is retrospective descriptive study.

\section{RESULTS}

The total number of patients attended both the OPDs during the above period of 5 years is $1,98,250$. Out of which, 42 cases were of parotid neoplasms. The incidence of parotid neoplasms among both OPDs is $0.0211 \%$. The present study of 42 cases exhibit an incidence of $64.3 \%$ benign tumours and $35.7 \%$ malignant tumours with pleomorphic adenoma accounting for $85.18 \%$ of benign tumours and about $54.76 \%$ of all parotid neoplasms. Pleomorphic adenoma constituted the commonest pathology affecting the parotid gland, the commonest malignant tumour was mucoepidermoid carcinoma. The distribution of various tumours in comparison with Spiro's series ${ }^{[8]}$ and Eneroth series ${ }^{[9]}$ is given below which is almost consistent.

\begin{tabular}{|c|c|c|c|c|}
\hline & $\begin{array}{c}\text { No. of } \\
\text { Cases }\end{array}$ & $\begin{array}{c}\text { \% of Present } \\
\text { Series }\end{array}$ & $\begin{array}{c}\text { \% in Spiro's } \\
\text { Series }\end{array}$ & $\begin{array}{c}\text { Eneroth } \\
\text { Series }\end{array}$ \\
\hline $\begin{array}{c}\text { Pleomorphic } \\
\text { adenoma }\end{array}$ & 23 & 54.76 & 45.4 & 45.7 \\
\hline $\begin{array}{c}\text { Monomorphic } \\
\text { adenoma }\end{array}$ & 2 & 4.76 & 0.2 & - \\
\hline Warthin's tumour & 1 & 2.38 & 1 & 3.3 \\
\hline $\begin{array}{c}\text { Nonspecific benign } \\
\text { Mucoepidermoid } \\
\text { carcinoma }\end{array}$ & 1 & 2.38 & 1 & - \\
\hline $\begin{array}{c}\text { Malignant mixed } \\
\text { tumour }\end{array}$ & 3 & 7.14 & 5.7 & - \\
\hline $\begin{array}{c}\text { Adenoid cystic } \\
\text { carcinoma }\end{array}$ & 3 & 7.14 & 10 & 8.5 \\
\hline $\begin{array}{c}\text { Undifferentiated } \\
\text { carcinoma }\end{array}$ & 2 & 4.76 & 1.3 & - \\
\hline \multicolumn{7}{|c|}{ Lymphoma } & 1 & 2.38 & - & - \\
\hline $\begin{array}{c}\text { Table 1. Showing various Parotid Neoplasms encountered } \\
\text { in comparison with Spiro and Eneroth Series }\end{array}$ \\
\hline
\end{tabular}

\section{Age}

While the youngest patient was 12 years, the oldest patient in this series was 68 years old. The peak age incidence was in the 50 - 60 years' age group. The mean age was 51.05 years. The mean age of incidence in males was 55.4 years and in females was 46.7 years. The mean age is higher for malignant tumours, 57.4 years compared to benign tumours 44.7 years.

\begin{tabular}{|c|c|c|c|c|}
\hline Gender & Present & Fenn AS & $\begin{array}{c}\text { Benign } \\
\text { Tumours }\end{array}$ & $\begin{array}{c}\text { Malignant } \\
\text { Tumours }\end{array}$ \\
\hline Male & 23 & 31 & 13 & 8 \\
\hline Female & 19 & 26 & 14 & 7 \\
\hline Total & $\mathbf{4 2}$ & $\mathbf{5 7}$ & $\mathbf{2 7}$ & $\mathbf{1 5}$ \\
\hline Ratio & $1.21: 1$ & $1.2: 1$ & $1: 1.07$ & $1.14: 1$ \\
\hline \multicolumn{4}{|c|}{ Table 2. Sex Distribution of Parotid Tumours in } \\
comparison with Fenn AS Series \\
\hline
\end{tabular}

\section{Sex}

There were 23 male patients and 19 female patients in this series. The male: female ratio for benign tumours was almost equal. There was a slight female preponderance (1: 1.07). For malignant tumours, there was a slight male preponderance (Male: Female- 1:14: 1). This is in agreement with the study conducted by Fenn $A S,[10]$ where the male: female ratio is 1.2:1.

\section{Clinical Features}

In the present series, most of the cases have presented with painless swelling in the parotid region. In the present series 40 cases have originated from the superficial lobe of the parotid and 2 cases from the deep lobe. Painful swellings are found to be carcinoma of the parotid gland. Rapid growth, facial paralysis, pain as primary symptoms are associated with malignancy. Among the malignant tumours, $20 \%$ of cases presented with facial palsy and fixity to the underlying structures and lymph node metastasis is seen in $13.4 \%$ of cases in comparison with Spiro RH series ${ }^{[8]}$ which shows lymph node metastasis in $23 \%$ of cases and facial nerve involvement in $22 \%$ of cases.

\section{Surgery}

All cases were treated primarily by surgery. Surgical procedures offered in this series are Superficial Parotidectomy (40.47\%), Total Conservative Parotidectomy (28.57\%), Total Parotidectomy (2.38\%) and Radical Parotidectomy (9.52\%). One patient with NHL underwent total conservative parotidectomy. In our series, all cases of malignant parotid tumours after radical surgery received adjuvant radiotherapy.

\begin{tabular}{|c|c|c|}
\hline Clinical Features of Malignancy & Present \% & Spiro RH \% \\
\hline Facial nerve palsy & 20 & 22 \\
\hline Lymph node metastasis & 13.4 & 23 \\
\hline Fixity to underlying structures & 20 & - \\
\hline $\begin{array}{c}\text { Table 3. Percentage of Parotid Neoplasms showing } \\
\text { features of Malignancy in comparison with Spiro Series }\end{array}$ \\
\hline
\end{tabular}

These results are comparable with Liverstein H.[11]

\begin{tabular}{|c|c|c|c|}
\hline 1 & Superficial parotidectomy & 17 & $40.47 \%$ \\
\hline 2 & Total conservative parotidectomy & 12 & $28.57 \%$ \\
\hline 3 & Total parotidectomy & 1 & $2.38 \%$ \\
\hline 4 & Radical parotidectomy & 4 & $9.52 \%$ \\
\hline 5 & $\begin{array}{c}\text { Radical parotidectomy with nerve } \\
\text { grafting }\end{array}$ & 1 & $2.38 \%$ \\
\hline 6 & Excision & 5 & $11.9 \%$ \\
\hline 7 & Enucleation (from deep lobe) & 2 & $4.76 \%$ \\
\hline
\end{tabular}

Table 4. Various Surgical procedures done for Parotid Neoplasms

Post-operative complications like Temporary facial palsy seen in 17 cases, Permanent facial palsy seen in 2 cases, Salivary fistula seen in 2 cases, Wound infection seen in 2 cases and Frey's syndrome was not recorded in any case. These results were consistent with Owen ERTC et al.[12]

\begin{tabular}{|c|c|c|}
\hline Surgery & Present Study & Liverstein $\mathrm{H}$ \\
\hline Superficial parotidectomy & $40.47 \%$ & $24.89 \%$ \\
\hline Total parotidectomy & $28.57 \%$ & $53.86 \%$ \\
\hline Radical parotidectomy & $9.52 \%$ & $3.27 \%$ \\
\hline Others & - & - \\
\hline
\end{tabular}




\begin{tabular}{|c|c|c|}
\hline Post-Operative Complications & $\begin{array}{l}\text { Present } \\
\text { Study }\end{array}$ & $\begin{array}{c}\text { Owen ERTC } \\
\text { et al }\end{array}$ \\
\hline Temporary facial weakness & $40.47 \%$ & $38 \%$ \\
\hline $\begin{array}{l}\text { Permanent facial palsy and } \\
\text { exposure keratitis }\end{array}$ & $5 \%$ & $9 \%$ \\
\hline Salivary fistula & $5 \%$ & $2 \%$ \\
\hline Wound infection & $5 \%$ & - \\
\hline Frey's syndrome & Nil & $11 \%$ \\
\hline \multicolumn{3}{|c|}{$\begin{array}{l}\text { Table 6. Various Post-Operative Complications } \\
\text { encountered in comparison with Owen Series }\end{array}$} \\
\hline
\end{tabular}

Temporary facial paralysis was seen in $40.47 \%$ of patients in our study. All occurred in patients with superficial parotidectomy. None in superficial parotidectomy, normal function returned in $4-6$ months. It may be due to nerve ischaemia, fatigue from excessive stimulation or stretching. However, permanent facial paralysis was seen in $5 \%$ as compared to $9 \%$ of Owen's study. Salivary fistula developed in $5 \%$ of patients as compared to $2 \%$ of Owen's study. None of the patients had complaints of Frey's syndrome, which was seen in $11 \%$ of patients in Owen ERTC et al study.[12] Cervical branch of facial nerve was paralysed in 2 out of 4 submandibular surgery. None of these parotid tumours showed recurrence over a period of 1 year and malignant tumour of submandibular had local recurrence at 1 year (5\%).

\section{Prognosis of Parotid Tumours}

Prognosis is very good provided the policy of early treatment and wide excision of tumour is carried out. Mortality in case of benign tumours is almost nil and life expectancy is about normal. Survey of literature shows that these tumours rarely prove detrimental to the life unless they have turned malignant with extensive local infiltration and metastasis. Mortality in the present series, followed for six months to two years is nil.

\section{DISCUSSION}

Parotid gland is the commonest site for salivary gland tumours.[2,8] About $64 \%$ - $80 \%$ of primary salivary gland epithelial tumours are seen in parotid gland, mostly in superficial lobe.[13] Our study comprises of 42 cases of benign and malignant tumours of the parotid gland. The peak age incidence was in the 50 - 60 years' age group. The mean age was 51.05 years. The mean age is higher for malignant tumours of 57.4 years compared to benign tumours of 44.7 years. Auclair P reported peak age incidence of salivary gland tumours is $6^{\text {th }}$ and $7^{\text {th }}$ decade of life with mean age of 46 years. ${ }^{[3]}$ Satko et al[14] reported mean age incidence of 53 years. The mean age is higher for malignant tumours around 55 years compared to benign tumours around 45 years.[2,8,15] The male: female ratio for benign tumours was almost equal. There was a slight female preponderance (1: 1.07). For malignant tumours, there was a slight male preponderance (Male: Female- 1:14:1). This is in agreement with the study conducted by Fenn AS,[10] where the male: female ratio is 1.2:1. In our study, the incidence of benign tumours was $64.3 \%$ and malignant tumours was $35.7 \%$ with Pleomorphic adenoma accounting for $85.18 \%$ of benign tumours and about $54.76 \%$ of all parotid neoplasms. Commonest complaint of patients with parotid tumours is painless swelling in the parotid region. Around 53\% of parotid tumours which are malignant, manifested with signs of malignancy such as facial palsy, fixity to underlying structures and lymph node metastasis, remaining $47 \%$ did not show the symptoms of malignancy which was consistent with the study conducted by Snow GB.[15] Pleomorphic adenoma and Warthin's tumours are commonest of benign tumours of parotid gland. This is consistent with the studies conducted by Spiro[8] and Eneroth. ${ }^{[9]}$

Malignant tumours consist of $35.7 \%$ of parotid tumours among which Mucoepidermoid carcinoma is the commonest followed by Adenoid Cystic carcinoma. This is consistent with the study conducted by Ellis GL et al, Spiro RH and Ito FA et al. $[1,8,14]$

Treatment of choice for parotid gland tumours is parotidectomy preserving the facial nerve.[15] Excision of the entire superficial lobe of parotid will give adequate surgical margins and avoids rupture of capsule and reduces the recurrence rate.[16] In our series, Superficial Parotidectomy was done for all cases of benign parotid tumours. The treatment of choice for malignant parotid tumours is Partial or Total parotidectomy with preservation of facial nerve if possible. In our series, 12 cases of malignant tumours' facial nerve was preserved, in 5 cases radical parotidectomy was done by sacrificing the facial nerve and in one case facial nerve grafting could be done. Adjuvant radiotherapy will help in improving the local control and survival.[7,17] In our series, all cases of malignant parotid tumours after radical surgery received adjuvant radiotherapy.

\section{CONCLUSION}

Parotid gland is the commonest site for salivary gland tumours.[2,8] About $64 \%$ - $80 \%$ of primary salivary gland epithelial tumours are seen in parotid gland, mostly in superficial lobe.[13] The peak age incidence was in the $50-60$ years' age group. The mean age was 51.05 years. The mean age is higher for malignant tumours of $\mathbf{5 7 . 4}$ years compared to benign tumours of 44.7 years. The male: female ratio for benign tumours was almost equal. There was a slight female preponderance (1:1.07). For malignant tumours, there was a slight male preponderance (Male: Female- 1:14: 1). In our study, the incidence of benign tumours was $64.3 \%$ and malignant tumours was $35.7 \%$ with Pleomorphic adenoma accounting for $85.18 \%$ of benign tumours and about $54.76 \%$ of all parotid neoplasms. Commonest complaint of patients with parotid tumours is painless swelling in the parotid region. Pleomorphic adenoma and Warthin's tumours are commonest benign tumours of parotid gland. Malignant tumours consist of $35.7 \%$ of parotid tumours, among which Mucoepidermoid carcinoma is the commonest followed by Adenoid Cystic Carcinoma. Treatment of choice for parotid gland tumours is parotidectomy preserving the facial nerve.[15] Excision of the entire superficial lobe of parotid will give adequate surgical margins and avoids rupture of capsule and reduces the recurrence rate.[16]

\section{REFERENCES}

[1] Ellis GL, Auclair PL. Tumors of the salivary glands. $3^{\text {rd }}$ edn. fascicle 17. Washington DC: Armed Forces Institute of Pathology; 1996.

[2] Eveson JW, Cawson RA. Salivary gland tumors. A review 2410 cases with particular reference to histological types, site age and sex distribution. J Pathol 1985;146(1):51-8. 
[3] Auclair PL, Ellis GL. Salivary gland neoplasms: general considerations. In: Ellis GL, Auclair PL, Gnepp DR, eds. Surgical pathology of the salivary glands. Philadelphia: WB Saunders; 1991:135-64.

[4] Nagler RM, Laufer D. Tumors of the major and minor salivary glands: review of 25 years of experience. Anticancer Res 1997;17(1B):701-7.

[5] Pinkston JA, Cole P. Incidence rates of salivary gland tumor: results from a population based study. Otolaryngol Head Neck Surg 1999;120(6):834-40.

[6] Yu GY, Ma DQ. Carcinoma of the salivary gland: a clinicopathological study of 405 cases. Semin Surg Oncol 1987;3(4):240-4.

[7] Pires FR, de Almeida OP, de Araujo VC, et al. Prognostic factors in head and neck mucoepidermoid carcinoma. Arch Otolaryngol Head Neck Surg 2004;130(2):174-80.

[8] Spiro RH. Salivary neoplasms: overview of a 35-year experience with 2,807 patients. Head Neck Surg 1986;8(3):177-84.

[9] Eneroth CM. Salivary gland tumors in the parotid gland, submandibular gland and the palate region. Cancer 1971;27(6):1415-8.

[10] Fenn AS, Gammon KL, Krishnan KV, et al. Salivary gland tumors. Ind J Surg 1982;44:101-4.
[11] Leverstein $\mathrm{H}$, van der Wal JE, Tiwari RM, et al. Malignant epithelial parotid gland tumors: analysis and results in 65 previously untreated patients. British Journal of Surgery 1998;85(9):1267-72.

[12] Owen ER, Banerjee AK, Kissin M, et al. Complications of parotid surgery: the need for selectivity. Br J Surg 1989;76(10):1034-5.

[13] Satko I, Stanko P, Longauerová I. Salivary gland tumours treated in the stomatological clinics in Bratislava. Cranio-Maxillo-Facial Surg 2000;28(1):5661.

[14] Ito FA, Ito K, Vargas PA, et al. Salivary gland tumors in a Brazilian population: a retrospective study of 496 cases. Int J Oral Maxillofac Surg 2005;34(5):533-6.

[15] Snow GB. Tumours of the parotid gland. Clin Otolaryngol 1979;4(6):457-8.

[16] Leverstein H, van der Wal JE, Tiwari RM, et al. Surgical management of 246 previously untreated pleomorphic adenomas of the parotid gland. Br J Surg 1997;84(3):399-403.

[17] Spiro IJ, Wang CC, Montgomery WW. Carcinoma of the parotid gland. Analysis of treatment results and patterns of failure after combined surgery and radiation therapy. Cancer 1993;71(9):2699-705. 